\title{
The incremental information content of AC 201 inflation-adjusted data
}

\author{
D.P. du Plessis \\ Sanlam Investments, Sanlamhof
}

A.A. Archer

University of Stellenbosch Business School, Bellville

\author{
J.F. Affleck-Graves \\ Graduate School of Business, University of Cape Town, Rondebosch
}

In this article an attempt is made to examine the extent to which inflation-adjusted income figures (derived from AC 201 data) contain information not included in the historic figures currently reported. The usefulness (or information content) criterion is examined from the aggregate market perspective through an empirical examination struc. tured to determine which set of figures best represents the information impounded in share prices. The research design incorporates a two-stage regression approach which permits a determination of the incremental explanatory power of collinear variables. The results obtained suggest that there are information content differences between inflation-adjusted and historic data as measured through the association with share returns. Only for those companies affected to a lesser extent by the effects of inflation could no discernable difference in information content be detected. Bar this exception, the results appear to support the hypothesis that inflation-adjusted data contain information that is on aggregate not reflected in the financial reports currently produced. However, the contention that historic income also possesses information beyond that provided by inflationadjusted income is not supported by the results. The research findings have important implications for reporting policy in SA regarding the future of inflation accounting requirements and seem to suggest that the SA Institute of Chartered Accountants should seriously consider making a form of inflation accounting mandatory. S. Afr. J. Bus. Mgrnt. 1986, 17: $1-6$

In hierdie artikel word gepoog om te bepaal in watter mate inflasie aangepaste inkomstesyfers (verkry uit RE 201-data) inligting bevat wat nie ingesluit is in die historiese syfers wat tans gepubliseer word nie. Die kriterium ten opsigte van nuttigheid (of inligtingsinhoud) word ondersoek uit die globalemark-perspektief deur middel van 'n empiriese ondersoek wat daarop ingestel is om te bepaal watter stel syfers die inligting vervat in aandeelpryse die beste weergee. Die navorsingsmetodiek omvat 'n twee-fase-regressiebenadering, wat die vasstelling van die ekstra verduidelikingskrag van saamlynige veranderlikes moontlik maak. Resultate dui daarop dat daar verskilie in inligtingsinhoud bestaan tussen inflasie-aangepaste- en historiese data, soos gemeet deur die verband met aandeelopbrengste. Slegs by daardie maatskappye wat in 'n mindere mate deur die uitwerking van inflasie beïnvioed is, kon geen opmerklike verskille in inligtingsinhoud waargeneem word nie. Benewens hierdie uitsondering, skyn die resultate die hipotese te ondersteun dat inflasie-aangepaste data inligting bevat wat, globaal geneem, nie weergegee word in die finansiële verslae wat tans verskyn nie. Daarenteen word die bewering dat historiese inkomste ook inligting bevat bo en behalwe dié weergegee deur die inflasieaangepaste inkomste, nie deur die resultate bevestig nie. Hierdie na. vorsingsresultate het belangrike implikasies vir die rekeningkundige beleid in SA met betrekking tot die toekoms van die vereistes van in. flasieboekhouding en skyn daarop te dui dat die Suid-Afrikaanse Instituut van Geoktrooieerde Rekenmeesters dit ernstig moet oorweeg om 'n vorm van inflasieboekhouding verpligtend te maak.

S. Afr. Tydskr. Bedryfsl. 1986, 17: $1-6$

\section{D.P. du Plessis}

Sanlam Investments, P.O. Box 1, Sanlamhof, 7532 Republic of South Africa

A.A. Archer*

University of Stellenbosch Business School, P.O. Box 610, Bellville, 7530

Republic of South Africa

J.F. Afneck-Graves

Graduate School of Business, University of Cape Town, Private Bag,

Rondebosch, 7700 Republic of South Africa

*To whom correspondence should be addressed

Accepted August 1985

\section{Introduction}

The debate as to whether companies should be required to report inflation-adjusted data, and if so, what the nature of the requirements should be, has drawn renewed attention in recent years. This has occurred because of the high rates of inflation since the early seventies and the prospect that relatively high levels may persist in South Africa (SA) in the future.

This study focuses on a particular form of accounting for changes in price levels - that recommended by the then National Council of Chartered Accountants (SA) (now called the SA Institute of Chartered Accountants) in Guideline AC 201 (formerly Guideline 4.003) of August 1978. In publishing Guideline AC 201, the accounting profession in SA paved the way for inflation-adjusted data to be disclosed. However, to date only a few companies have experimented with the recommendations of this guideline. A possible reason for this is that no company will of its own free choice publish inflation-adjusted results if this could adversely affect its market rating.

The SA Institute of Chartered Accountants may take further action once evidence has been submitted that inflation-adjusted figures are useful to the users of accounting data, i.e. that inflation-adjusted income convey information beyond that which is currently available in historic cost reports. An investigation into the usefulness of the alternative/supplemental sets of figures is therefore a research question with important implications in SA for public policy regarding the future of inflation accounting requirements. The purpose of this study is to submit evidence to this question.

An analysis was therefore undertaken to explore the extent to which inflation-adjusted data contain information not included in the historic data currently reported (i.e. the information content of the inflation-adjusted data set which is in excess of that which is contained in the related historic income figures). The usefulness (or information content) criterion was examined from the aggregate market perspective through an empirical examination structured to determine which set of figures best represents the information impounded in share prices.

\section{Data}

The initial set of companies considered in this study consisted of all companies, listed in the industrial section of the Johannesburg Stock Exchange (JSE), with financial years ended in the calender years $1975-1982$.

The final sample was produced by applying five sample selection criteria to the initial set of companies. Companies 
conforming to the criteria enumerated below, ranging from the most to the least restrictive, were excluded for research purposes:

(i) companies with financial years not ending on June 30 for the entire period;

(ii) holding companies that carried no stockholding, and/or where the major investment was represented by another sample constituent;

(iii) companies that experienced severe structural changes, including those of which the listings were shifted from the industrial to other sections of the JSE;

(iv) companies for which reasonable estimates of inflationadjusted data could not be made readily; and

(v) companies of which the listings were suspended for excessively long periods.

The first requirement necessitated the exclusion of a considerable proportion of the companies. This extremely restrictive criterion was required because the methodology employed in this study necessitated the calculation of financial year-onyear differences in historic income and inflation-adjusted income respectively. These differences were then divided (or scaled) by a balance sheet deflator. A change in the financial year end of a particular company would therefore necessitate an annualization of the variables concerned. The somewhat haphazard customary adjustment procedure was avoided by restricting the sample to companies with the same financial year throughout the covered period. June 30 proved to be the most common reporting date for those companies that had maintained the same financial year over the entire period.

Application of the sample selection criteria produced a sample of 59 companies.

The analysis focused upon two informational variables, i.e. the annual change in historic income and the annual change in inflation-adjusted income, and their relationship with annual share returns. These variables are discussed in turn in the following paragraphs.

\section{Historic income}

Historic income was for the purpose of this study defined as earnings available for ordinary shareholders, based on consolidated net income for the financial period, after ordinary and foreign taxation, and after deducting outside shareholders' interests and preference dividends, but before extraordinary and abnormal items.

Historic income for a group of companies was therefore based on operating profits attributable to members of the holding company. Deferred taxation was excluded from the calculation in an attempt to avoid possible distortions being introduced as a result of extreme fluctuations in this taxation component. Where the earnings of associated companies were included in a company's income statement, the historic income was based on profits exclusive of associated companies' results.

The annual change in historic income was formulated as follows.

$$
\mathrm{HC}_{i, t}=\frac{\mathrm{HI}_{i, t}-\mathrm{HI}_{i, t-1}}{\frac{1}{3}\left(\mathrm{NAV}_{i, t}+\mathrm{NAV}_{i, t-1}+\mathrm{NAV}_{i, t-2)}\right.}
$$

where $\mathrm{HC}_{i, t}=$ change in historic income of company $i$ in period $t ; \mathrm{HI}_{i, t}=$ historic income of company $i$ in period $t$; and $\mathrm{NAV}_{i, t}=$ net asset value of company $i$ at the end of period $t$.

Net asset value was computed by adding all the assets (excluding intangibles), and then subtracting all liabilities, preference share capital, outside shareholders' interests, deferred taxation and revaluation surpluses. Similar deflators were used by Bar-Yosef \& Lev (1983:43) and Morris \& McDonald (1982:388).

\section{Inflation-adjusted income}

Inflation-adjusted income was for the purpose of this study defined as historic income (see definition above) adjusted for the effects of changing price levels, in accordance with the recommendations of Guideline AC 201. (Inflation adjustments were generated by means of the inflation accounting model of the University of Stellenbosch Business School. The reader is referred to Archer (1980:94 - 141) for a detailed discussion of this model.) The portion of the inflation-adjustment accruing to outside shareholders' interests was taken into consideration in arriving at the estimate for inflation-adjusted income. If price levels did not change, inflation-adjusted income and historic income would, of course, have been identical.

It should be noted that a few of the companies included in the study published inflation-adjusted data in the form of a supplementary current cost income statement. In order to facilitate uniformity in the adjustment procedure, such company-year observations were excluded. In addition, companies which employed the flip-flop LIFO (last-in-first-out) accounting method, which circumvents any reported earnings reduction that would otherwise have arisen with the use of the LIFO method of stock valuation, were also excluded.

The annual change in inflation-adjusted income was formulated as follows.

$$
\mathbf{R C}_{i, t}=\frac{\mathrm{RI}_{i, t}-\mathbf{R I}_{i, t-1}}{\frac{1}{3}\left(\mathrm{NAV}_{i, t}+\mathrm{NAV}_{i, t-1}+\mathrm{NAV}_{i, t-2}\right)}
$$

where $\mathrm{RC}_{i, t}=$ change in inflation-adjusted income of company $i$ in period $t$; and $\mathbf{R I}_{i, t}=$ inflation-adjusted income of company $i$ in period $t$. All other symbols are as described before.

\section{Share retums}

A cumulative abnormal return (CAR) was computed for each company for the duration of each financial year from 1976 through 1982, using intercept and slope coefficients estimated from a time series regression based on the previous two years. The initial financial year holding period assumption was then extended to include four alternative annual holding periods (starting with September 30 through September 30 and ending with December 31 through December 31).

The CAR was computed as follows.

(i) Price relative returns (i.e. returns unadjusted for risk) were calculated for a company's ordinary shares on a bi-weekly basis, using the following formulation.

$$
R_{i, t}=\frac{P_{i, t}-P_{i, t-1}+D_{i, t}}{P_{i, t-1}}
$$

where $R_{i, t}=$ ex post (i.e. realized) return on share $i$ in period $t ; P_{i, t}=$ closing price of share $i$ at the end of period $t$; and $D_{i, t}=$ dividend of share $i$ in period $t$ (i.e. exdividend date vithin period $t$ );

(ii) Returns on the maket, as represented by appropriate share-price and disidend indices, were calculated as follows.

$$
R_{m, t}=\left(\frac{I_{m, t}}{I_{m, t-1}} \cdot \frac{I_{m, t-1}}{1}\right)+\left(\frac{D I_{m, t}}{100} \times \frac{n}{365}\right)
$$

where $R_{m, t}=$ ex post :eturn of market portfolio in period $t$ (the JSE Actuaries Industrial share-price and dividend indices were used as a surrogate for the market); $I_{m, t}=$ index value at the end of period $t ; D I_{m, t}=$ dividend index 
of market portfolio (expressed in percentage terms) at the end of period $t$; and $n=$ number of days between the end of period $t$ and the end of period $t-1$.

(iii) Because this study evaluates informational variables as they relate to the individual company, their information content should be assessed relative to changes in the rate of return on the company's shares net of market-wide effects. This step therefore involved the elimination of the overall market effects from price relative returns and the adjustment for the risk level of the share, using the familiar market model (Markowitz, 1952 and Sharpe, 1963).

$R_{i, t}=\alpha_{i}+\beta_{i} R_{m, t}+e_{i, t}$

where $e_{i, t}=$ residual (or abnormal) return for share $i$ in period $t$; and $\alpha_{i}, \beta_{i}=$ regression parameters. All other symbols are as described before.

Using the estimated regression parameters, $\hat{\alpha}$ and $\hat{\beta}$, the bi-weekly abnormal return for share $i$ can be estimated as follows

$\hat{e}_{i, t}=R_{i, t}-\hat{R}_{i, t}$

where $\hat{R}_{i, t}=$ expected return on share $i$ in period $t\left(\hat{R}_{i, t}\right.$ $\left.=\hat{\alpha}_{i, l}+\hat{\beta}_{i} R_{m, t}\right)$. All other symbols are as described before.

As the above procedure abstracts from the general market conditions and the market is believed to adjust reasonably quickly and efficiently to new information, the residuals will represent the impact of new information about company $i$ alone.

(iv) The series of bi-weekly abnormal returns were aggregated into annual measures, using the following methodology.

$\mathrm{CAR}_{i, T}=\sum_{i=1}^{n_{1}} e_{i, t}$

where $\mathrm{CAR}_{i, T}=$ cumulative abnormal return of company $i$ in period $T$; and $n_{T}=$ number of bi-weekly intervals in period $T$. All other symbols are as described before.

Note that hereafter $t$ will denote year $t$, rather than a biweekly interval.

The CAR measures the cumulative effects of the deviations of the share returns from their normal relationship with the market (Fama, Fisher, Jensen \& Roll, 1969: 8). The CAR can clearly be either systematically positive or negative (i.e. non-zero), or can display unsystematic (i.e. zero) residual behaviour. This CAR was used as dependent variable in the two-stage regression analysis described below and together with the $\mathrm{HC}$ and RC series formed the basic data used in this study.

\section{Research methodology}

From an informational perspective the central issue in this study revolves around the following two questions:

(i) Do inflation-adjusted income figures provide information (i.e. additional explanatory power) over and above that provided by historic income figures?

(ii) Do historic income figures provide information over and above that provided by inflation-adjusted income figures?

Accordingly, these are the two hypotheses that will be tested.

It is important to note that the two earnings variables are not necessarily mutually exclusive regarding their respective information content. Both historic income and inflationadjusted income share common factors that could explain a cross-sectional variation in share returns. The level of explanatory power provided by knowledge of more than one variable must therefore be compared with the explanatory power provided by knowledge of only one of the variables.

To examine this issue, two-stage regression analyses were conducted. The approach adopted was similar to that employed by Bar-Yosef \& Lev (1983); Beaver, Griffin \& Landsman (1982); and Patell \& Kaplan (in Beaver, Griffin \& Landsman, 1982:27) and consisted of conducting regressions across all company-year observations, i.e. a pooled cross-sectional approach. This particular procedure was adopted for the following reasons.

(i) When the independent variables in a regression are correlated among themselves, intercorrelation or multicollinearity is said to exist among them. The presence of multicollinearity makes the interpretation of results difficult and misleading. In particular, the incremental explanatory power of each informational variable becomes blurred. Incorporating several earnings measures in one regression equation as independent variables, would clearly result in multicollinearity. The two-stage regression approach, however, permits the determination of the incremental (i.e. additional) explanatory power of collinear variables.

(ii) The earnings variables are not treated as being mutually exclusive.

(iii) The magnitude as well as the sign of the earnings variables are incorporated.

The incremental information content of inflation. adjusted income

This section deals with an examination of the first hypothesis, namely that inflation-adjusted income does not provide information over and above that provided by historic income figures. The methodology employed is briefly summarized below.

(i) The annual change in inflation-adjusted income, RC, was regressed on the annual change in historic income, $\mathrm{HC}$, to obtain a residual, $Z$, which is by construction uncorrelated with $\mathrm{HC}$.

$\mathrm{RC}_{i, t}=\alpha+\beta \mathrm{HC}_{i, t}+Z_{i, t}$

where $R C_{i, l}=$ change in inflation-adjusted income of company $i$ in period $t ; \mathrm{HC}_{i, t}=$ change in historic income of company $i$ in period $t ; Z_{i, t}=$ random disturbance (or residual) variable of company $i$ in period $t$; and $\alpha, \beta=$ regression parameters.

The ordinary least squares estimate of $\beta$ was $0,99(t$ value of 68,20 ). The value of the $R^{2}$ statistic was 0,92 which is significant at the $1 \%$ level. It can therefore be concluded that a significant proportion of the information content of inflation-adjusted income is also included in the historic figure.

(ii) The annual cumulative abnormal return, CAR, was then regressed on $H C$ and $Z$.

$\mathrm{CAR}_{i, t}=\alpha+\beta_{2} \mathrm{HC}_{i, t}+\beta_{2} Z_{i, t}+U_{i, t}$

where $\mathrm{CAR}_{i, t}=$ cumulative abnormal return of company $i$ in period $t$; and $U_{i, t}=$ random disturbance variable of company $i$ in period $t$. All other symbols are as described before.

If $\mathrm{RC}$ possesses information not provided by $\mathrm{HC}$, the regression coefficient, $\beta_{2}$, on the residual, $Z$, should be different from zero. The null hypothesis therefore states that the regression coefficient, $\beta_{2}$, in the popula- 
tion is not different from zero (i.e. $\mathrm{RC}$ does not possess explanatory power not provided by $\mathrm{HC}$ ).

(iii) This hypothesis was tested using the familiar $t$ test.

Results for the second-stage regression are summarized in Table 1 . It can be seen that the $\beta_{2}$ coefficient is insignificant at conventional levels in all the holding periods examined. One is therefore unable to reject the null hypothesis and hence cannot conclude that inflation-adjusted income figures possessed information beyond that provided by the historic figures.

Table 1 Incremental information content of inflationadjusted income: summary of results for second-stage regressions

\begin{tabular}{lccccc}
\hline & \multicolumn{5}{c}{ Holding period ended } \\
\cline { 2 - 6 } & Jun & Sept & Oct & Nov & Dec \\
\hline$\beta_{1}$ value & 0,79 & 1,01 & 1,11 & 1,05 & 1,11 \\
$\beta_{2}$ & $4,41^{\text {a }}$ & $6,31^{\mathrm{a}}$ & $6,65^{\mathrm{a}}$ & $6,11^{\mathrm{a}}$ & $6,27^{\mathrm{a}}$ \\
$t$ value & 0,18 & 0,68 & 0,48 & 0,89 & 1,01 \\
$R^{2}$ & 0,29 & 1,20 & 0,82 & 1,48 & 1,62 \\
$\begin{array}{l}\text { Number of } \\
\text { companies }\end{array}$ & 0,05 & 0,10 & 0,10 & 0,09 & 0,10 \\
$\begin{array}{l}\text { Number of } \\
\text { company-year } \\
\text { observations }\end{array}$ & 59 & 59 & 59 & 59 & 59 \\
\hline
\end{tabular}

${ }^{\mathrm{a} D e n o t e s}$ significance at the $5 \%$ level.

The incremental information content of historic income It could perhaps be argued that the former procedure was a rather severe test to impose on inflation-adjusted income. If $\mathrm{RC}$ and $\mathrm{HC}$ are highly correlated, it is not unreasonable to believe that the two variables possess a considerable amount of common explanatory power with respect to share returns (i.e. the informational variables are not mutually exclusive). In this section the two-stage model was therefore reversed and run in the opposite direction.

The procedure employed was as follows.

(i) $\mathrm{HC}$ was regressed on $\mathrm{RC}$ to obtain a residual, $Z$, which is by construction uncorrelated with RC.

$\mathrm{HC}_{i, t}=\alpha+\beta \mathrm{RC}_{i, t}+Z_{i, t}$

where all the symbols are as described before.

This regression yielded a $\beta$ estimate of 0,94 ( $t$ value of 68,20 ) and an $R^{2}$ statistic of 0,92 which, as before, is significant at the $1 \%$ level.

(ii) The CAR was then regressed on $R C$ and $Z$.

$\mathrm{CAR}_{i, t}=\alpha+\beta_{1} \mathrm{RC}_{i, t}+\beta_{2} Z_{i, t}+U_{i, t}$

where all the symbols are as described before.

If $\mathrm{HC}$ possesses information not provided by $\mathrm{RC}$, the regression coefficient, $\beta_{2}$, on the residual, $Z$, should be different from zero. The null hypothesis therefore states that the regression coefficient, $\beta_{2}$, in the population is not different from zero (i.e. HC does not possess explanatory power not provided by $\mathrm{RC}$ ).

(iii) This hypothesis was tested using the familiar $t$ test.

Results for the second-stage regression are summarized in Table 2. Analysis of the results indicates that once again none of the $\beta_{2}$ coefficients were significantly different from zero at conventional levels. Therefore one cannot conclude that historic income figures possess information beyond that provided by inflation-adjusted figures.
Table 2 Incremental information content of historic income: summary of results for second-stage regressions

\begin{tabular}{lccccc}
\hline & \multicolumn{5}{c}{ Holding period ended } \\
\cline { 2 - 6 } & Jun & Sept & Oct & Nov & Dec \\
\hline$\beta_{1}$ & 0,75 & 1,00 & 1,08 & 1,05 & 1,12 \\
$t$ value & $4,31^{\mathrm{a}}$ & $6,40^{\mathrm{a}}$ & $6,62^{\mathrm{a}}$ & $6,28^{\mathrm{a}}$ & $6,48^{\mathrm{a}}$ \\
$\beta_{2}$ & 0,61 & 0,34 & 0,64 & 0,17 & 0,11 \\
$t$ value & 0,95 & 0,59 & 1,05 & 0,27 & 0,18 \\
$R^{2}$ & 0,05 & 0,10 & 0,10 & 0,09 & 0,10 \\
$\begin{array}{l}\text { Number of } \\
\text { companies }\end{array}$ & 59 & 59 & 59 & 59 & 59 \\
$\begin{array}{l}\text { Number of } \\
\text { company-year } \\
\text { observations }\end{array}$ & 388 & 388 & 388 & 388 & 388 \\
\hline
\end{tabular}

aDenotes significance at the $5 \%$ level.

The results presented in the previous two sections, appear to suggest that both sets of figures are substitutes for one another. In both cases the value of the $R^{2}$ statistic in the firststage regression was of the order 0,90 , indicating that about $90 \%$ of the variation in one income measure can be explained by the other income measure. The results of the second-stage regression indicate that the remaining variation (i.e. approximately $10 \%$ ) does not significantly explain the CAR. Consequently there seems little value in requiring both historic and inflation-adjusted figures to be reported.

\section{The effect of inflation}

The foregoing results seem to indicate that little benefit would accrue to shareholders were it to become mandatory for companies to disclose both historic and inflation-adjusted income figures. Such a conclusion could, however, be an oversimplification because, in the absence of inflation, one would not expect the two sets of numbers to contain different information. Indeed, both Beaver, Christie \& Griffin (1980: 145) and Gheyara \& Boatsman (1980:114) structured their studies on the supposition that information content was more interesting for companies affected to a greater extent by inflation. Because the results presented in the previous two sections were averages of the entire sample of 59 companies, it is possible that the significance of the inflation-adjusted figures was dissipated by the presence of several companies relatively unaffected by inflation. It was therefore decided to repeat the analysis after segmenting the sample into three subgroups on the following basis.

Firstly, the companies were ranked in terms of the impact of inflation on their historic income. This impact was measured by the absolute difference between a company's historic income and inflation-adjusted income. In order to obtain a relative measure, this difference was scaled by the average net asset value on a historic cost basis.

The inflation impact was formulated as follows

$\mathrm{II}_{i, t}=\frac{\mathrm{RI}_{i, t}-\mathrm{HI}_{i, t}}{\frac{1}{2}\left(\mathrm{NAV}_{i, t}+\mathrm{NAV}_{i, t-1}\right)}$

where $\mathrm{II}_{i, r}=$ inflation impact of company $i$ in period $t ; \mathrm{RI}_{i, r}=$ inflation-adjusted income of company $i$ in period $t$; $\mathrm{HI}_{i, t}=$ historic income of company $i$ in period $t$; and $\mathrm{NAV}_{i, t}=$ net asset value of company $i$ at the end of period $t$.

The inflation impact was expressed in terms of an average figure, calculated as the arithmetic average of the series of annual figures over the duration of the research period. An average measure was used in an attempt to smooth possible 
wide fluctuations in the annual inflation impact as a result of factors pertaining to the economy.

The top end of the ranking comprised those companies suffering from severe inflationary pressure (i.e. companies where inflation had a large impact on historic income), whereas the tail end was made up of those that had been relatively successful in hedging inflation (i.e. companies where inflation had a small impact on historic income).

Finally, the average inflation impact figures were used to partition the ranked companies into three approximately equal-sized subgroups. These groups were labelled from A to $C$, with the companies in group $A$ being affected the most, and companies in group $C$ being affected the least by the impact of inflation on their historic income.

For the high inflation impact group (i.e. group A) the firststage regression resulted in an $R^{2}$ value of 0,87 , indicating that there was a high degree of co-movement between historic and inflation-adjusted income figures. Indeed, as much as $87 \%$ of the variation in one income figure could be explained by the other income figure.

Results for the second-stage regression are summarized in Table 3. It can be seen that the incremental information content of inflation-adjusted income, $\beta_{2}$ is significant in both the November and December holding periods. This would be consistent with the hypothesis that for the high inflation impact companies, inflation-adjusted income figures possess information in addition to that provided by historic figures.

The fact that $\beta_{2}$ was insignificant at conventional levels for the June, September and October holding periods, is a cause for some concern. However, Knight (1983:118) has shown that for SA companies, much of the information content in earnings numbers is unanticipated by the market. Consequently the lack of significance in the June, September and October holding periods, can probably be ascribed to the fact that not all of the companies had released their preliminary reports at these stages.

The converse, however, does not appear to hold, i.e. in none of the holding periods examined did the historic figures

Table 3 Incremental information content of inflationadjusted and historic income: summary of results for second-stage regressions for high inflation impact group (i.e. group A)

\begin{tabular}{|c|c|c|c|c|c|}
\hline \multirow{2}{*}{$\begin{array}{l}\text { Incremental } \\
\text { information content }\end{array}$} & \multicolumn{5}{|c|}{ Holding period ended } \\
\hline & Jun & Sept & Oct & Nov & Dec \\
\hline \multicolumn{6}{|l|}{$\begin{array}{l}\text { Inflation-adjusted } \\
\text { income: }\end{array}$} \\
\hline$\beta_{1}$ & 0,88 & 1,48 & 1,52 & 1,43 & 1,64 \\
\hline I value & $2,59^{\mathrm{b}}$ & $4,51^{b}$ & $4,35^{b}$ & $4,05^{b}$ & $4,55^{b}$ \\
\hline$\beta_{2}$ & $(1,07)$ & 1,44 & 1,02 & 2,56 & 2,69 \\
\hline$t$ value & $(1,09)$ & 1,52 & 1,02 & $2,52^{\mathrm{b}}$ & $2,58^{b}$ \\
\hline$R^{2}$ & 0,06 & 0,16 & 0,14 & 0,16 & 0,19 \\
\hline \multicolumn{6}{|l|}{ Historic income: } \\
\hline$\beta_{1}$ & 0,71 & 1,61 & 1,58 & 1,70 & 1,92 \\
\hline I value & $2,03^{b}$ & $4,76^{b}$ & $4,43^{b}$ & $4,68^{b}$ & $5,17^{b}$ \\
\hline$\beta_{2}$ & 1,85 & 0,17 & 0,59 & $(0,90)$ & $(0,80)$ \\
\hline$t$ value & $1,95^{\mathrm{a}}$ & 0,18 & 0,60 & $(0,91)$ & $(0,79)$ \\
\hline \multicolumn{3}{|l|}{ Number of } & 20 & 20 & 20 \\
\hline \multirow{2}{*}{$\begin{array}{l}\text { Number of } \\
\text { company-year } \\
\text { observations }\end{array}$} & & & & & \\
\hline & 122 & 122 & 122 & 122 & 122 \\
\hline
\end{tabular}

possess information beyond that provided by the inflationadjusted figures. Therefore, for the high inflation impact group it would appear that the two sets of figures do not provide identical information. The results in fact seem to suggest that two alternatives exist, namely:

(i) that both sets of income figures should be provided; or

(ii) if only one set of figures is to be provided it should be the inflation-adjusted figures.

For the low inflation impact group (i.e. group $C$ ), the firststage regression results yielded an $R^{2}$ value of 0,95 which indicates the $95 \%$ of the variation in one income measure could be explained by the other income measure. This is higher than the 0,87 for the high inflation impact group, but is to be expected as one would anticipate a higher degree of comovement between the two sets of income figures for the lower inflation impact group.

Results for the second-stage regression are summarized in Table 4 . None of the $\beta_{2}$ coefficients are significant which provides support for the hypothesis that both sets of income figures are substitutes for each other and neither possess any incremental information.

Table 4 Incremental information content of inflationadjusted and historic income: summary of results for second-stage regressions for low inflation impact group (i.e. group C)

\begin{tabular}{|c|c|c|c|c|c|}
\hline \multirow{2}{*}{$\begin{array}{l}\text { Incremental } \\
\text { information content }\end{array}$} & \multicolumn{5}{|c|}{ Holding period ended } \\
\hline & Jun & Sept & Oct & Nov & Dec \\
\hline \multicolumn{6}{|l|}{$\begin{array}{l}\text { Inflation-adjusted } \\
\text { income: }\end{array}$} \\
\hline $\begin{array}{l}\beta_{1} \\
l \text { value }\end{array}$ & $\begin{array}{l}2,73 \\
5,51^{a}\end{array}$ & $\begin{array}{l}1,82 \\
3,91^{a}\end{array}$ & $\begin{array}{l}1,67 \\
3,39^{\mathrm{a}}\end{array}$ & $\begin{array}{l}1,24 \\
2,59^{\mathrm{a}}\end{array}$ & $\begin{array}{l}1,55 \\
2,96^{\mathrm{a}}\end{array}$ \\
\hline $\begin{array}{l}\beta_{2} \\
t \text { value }\end{array}$ & $\begin{array}{l}1,49 \\
0,67\end{array}$ & $\begin{array}{l}3,09 \\
1,47\end{array}$ & $\begin{array}{l}2,75 \\
1,24\end{array}$ & $\begin{array}{l}1,84 \\
0,85\end{array}$ & $\begin{array}{l}2,70 \\
1,14\end{array}$ \\
\hline$R^{2}$ & 0,27 & 0,17 & 0,13 & 0,08 & 0,11 \\
\hline $\begin{array}{l}\text { Historic income: } \\
\quad \beta_{1} \\
t \text { value }\end{array}$ & $\begin{array}{l}2,73 \\
5,52^{\mathrm{a}}\end{array}$ & $\begin{array}{l}1,93 \\
4,14^{\mathrm{a}}\end{array}$ & $\begin{array}{l}1,76 \\
3,58^{\mathrm{a}}\end{array}$ & $\begin{array}{l}1,30 \\
2,71^{\mathrm{a}}\end{array}$ & $\begin{array}{l}1,65 \\
3,14^{\mathrm{a}}\end{array}$ \\
\hline $\begin{array}{l}\beta_{2} \\
t \text { value }\end{array}$ & $\begin{array}{l}1,28 \\
0,57\end{array}$ & $\begin{array}{l}(1,19) \\
(0,57)\end{array}$ & $\begin{array}{l}(1,02) \\
(0,46)\end{array}$ & $\begin{array}{l}(0,55) \\
(0.26)\end{array}$ & $\begin{array}{l}(1,08) \\
(0,46)\end{array}$ \\
\hline $\begin{array}{l}\text { Number of } \\
\text { companies }\end{array}$ & 15 & 15 & 15 & 15 & 15 \\
\hline $\begin{array}{l}\text { Number of } \\
\text { company-year } \\
\text { observations }\end{array}$ & 88 & 88 & 88 & 88 & 88 \\
\hline
\end{tabular}

In concluding this section, it can be said that the results obtained suggest that there are information content differences between inflation-adjusted and historic data as measured through the association with share returns. Only for those companies affected to a lesser extent by the effects of inflation could no discernable difference be detected in information content. For the high inflation impact group the results appear to support the hypothesis that inflation-adjusted data contain information which is on aggregate not reflected in the financial reports currently produced. However, the contention that historic income also possesses information beyond that provided by inflation-adjusted income is not supported by the results.

Although not of central concern to this study, it is nevertheless interesting to note that in all of the second-stage regressions, the $\beta_{1}$ coefficient was significant at the $5 \%$ level. This confirms that earnings information, whether in the form 
of historic income or inflation-adjusted income, does significantly explain abnormal returns of shares listed on the JSE. Moreover, an examination of the second-stage results indicates that the $t$ statistics are substantially higher for the September, October, November and December holding periods than for the June holding period. As previously mentioned this probably occurs because the release of the earnings information only occurs during the months September to December. These results therefore confirm those of Knight (1983: 130) who concluded that the actual release of the earnings number does provide information to shareholders; in other words that such information is not consistently anticipated by the market.

In order to remove any possible scepticism which may cloud the results obtained from a relatively small sample, the entire statistical analysis was duplicated for a holdout sample. The second (i.e. holdout) sample was chosen using the same criteria as applied to the initial set of companies, with the exception of the first criterion which was ammended to include companies having a financial year ended on December 31 for the entire period. In total 29 companies qualified for inclusion in the holdout sample.

The results obtained for the holdout sample (i.e. December year end companies) were similar to those obtained for the original sample (i.e. June year end companies). Hence the conclusions drawn can be considered to be valid for all companies during the period under study.

\section{Conclusions and Recommendations}

In this article an attempt has been made to examine the extent to which inflation-adjusted data contain information not included in the historic data currently reported. The usefulness (or information content) criterion was examined from the aggregate market perspective through an empirical examination structured to determine which set of figures best represented the information impounded in share prices. The main conclusions to be drawn from the results can be summarized as follows.

(i) Historic income and inflation-adjusted income are good substitutes for one another and each number can explain approximately $90 \%$ of the variability in the other measure.

(ii) Historic income does not appear to possess any information in addition to that provided by the related inflationadjusted figure.

(iii) In certain cases, particularly where a company is highly affected by inflation, the inflation-adjusted income figures do appear to possess information over and above that provided by the historic figures.

The conclusions must, however, be tempered with the usual caveats, i.e. the results might be due to:

(i) the particular methodology chosen;

(ii) the company-year observations investigated;

(iii) some extraneous factor; and

(iv) random events.

Although cognizance must be taken of these possible drawbacks, the results nevertheless indicate that in the absence of the disclosure of inflation-adjusted data, the research findings can be interpreted as an indication that market participants attempt to adjust historic data to changes in the purchasing power of money, and that they base their investment decisions on the restated data. If such an interpretation is plausible, and if, in addition, accountants have a relative advantage in producing financial data, it is possible that mandatory disclosure requirements for inflation-adjusted data could reduce the real resources needed to generate the restated data. This is true because such disclosure requirements would eliminate the need for market participants to adjust financial reports for changes in price levels, and shift the responsibility to companies and their accountants.

It should also be kept in mind that market participants and management are not the only audience of accounting disclosures. It is certainly possible that other audiences may find the disclosure of inflation-adjusted data informative. For example, legislative thinking regarding the merits of company tax on 'phantom profits' may be altered by such disclosure. In this regard it has to be borne in mind that inflation profits should not be distributed to shareholders, as capital has to be maintained in order to carry on business at the same levels as before. Similarly the fiscus should not claim taxes on these profits.

Furthermore, in a recent extensive analysis of international accounting standards, SA performed rather poorly (Sunday Times, Business Times, March 11, 1984). International Accounting Bulletin's Survey of Accounts and Accountants 1983/84 ranked SA 11 th of the 17 countries where 10 or more annual reports were analysed. Of particular significance is the fact that the analysis gave SA companies a poor rating on, among others, changing prices data.

It is therefore apparent that the SA Institute of Chartered Accountants should seriously consider making a form of inflation accounting mandatory.

\section{Acknowledgements}

The authors wish to acknowledge financial support by the Human Sciences Research Council, and programming assistance by Mr W.R. Gevers of the University of Stellenbosch Business School.

\section{References}

Accounting Practices Committee. 1978. Guideline on disclosure of effects of changing prices on financial results no AC 201 (formerly no 4.003). Johannesburg: National Council of Chartered Accountants (SA), 6p.

Archer, A.A. 1980. The relevance of Guideline 4.003 (of the SA Institute of Chartered Accountants) for financing and dividend policy decisions. Unpublished doctoral dissertation. University of Stellenbosch, 445p.

Bar-Yosef, S. \& Lev, B. March-April 1983. Historical cost earnings versus inflation-adjusted earnings in the dividend decision. Fin. Anal. J., 41-50.

Beaver, W.H., Christie, A.A. \& Griffin, P.A. August 1980. The information content of SEC Accounting Series Release No 190 J. Account. Econ., $131-157$.

Beaver, W.H., Griffin, P.A. \& Landsman, W.R. July 1982. The incremental information content of replacement cost earnings. J. Account. Econ., 15-39.

Fama, E.F., Fisher, L., Jensen, M.C. \& Roll, R. February 1969. The adjustment of stock prices to new information. Intern. Econ. Rev. 1-21.

Gheyara, K. \& Boatsman, J. August 1980. Market reaction to the 1976 replacement cost disclosures. J. Account. Econ., $107-125$

Knight, R.F, 1983. The association between published accounting data and the behaviour of share prices. Unpublished doctoral dissertation. University of Cape Town, 359p.

Markowitz, H. March 1952. Portfolio selection. J. Fin., 77-91.

Morris, M.H. \& McDonald, B. Autumn 1982. Asset pricing and financial reporting with changing prices. J. Bus. Fin. Account. $383-395$.

Sharpe, W.F. January 1963. A simplified model for portfolio analysis. Mgmt. Sci., 277-293.

Sunday Times, Business Times. March 11, 1984. 